Copyright (C) 2021 by Cherkas Global University

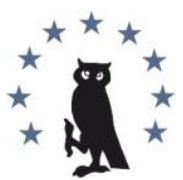

Published in the USA

Russkaya Starina

Has been issued since 2010.

E-ISSN: $2409-2118$

2021. 12(2): 119-128

DOI: $10.13187 /$ rs.2021.2.119

https://rs.cherkasgu.press

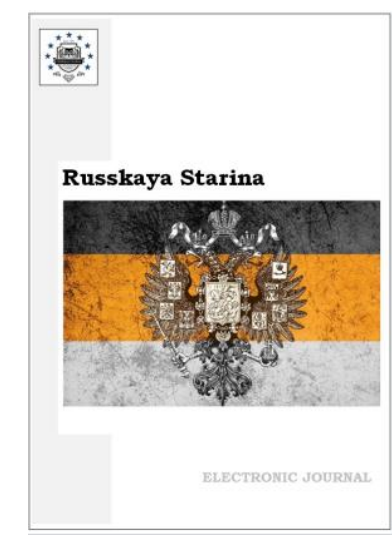

\title{
Memories and Research in History of Daugavpils Ghetto
}

Iosif G. Rochko a , *

a Museum “Jews in Daugavpils and Latgale”, Daugavpils, Latvia

\section{Abstract}

The Daugavpils ghetto existed from July 15, 1941 to October 28, 1943. More than 13,000 Jews passed through the ghetto gates. A little more than 100 survived. In the ghetto there were, like the Jews of Daugavpils and the surrounding area, small towns and townships of Latgale, as well as several thousand Jews from Lithuania. About ten former prisoners left diaries and memories of the terrible days, which are published and have survived to this day. Later, the works of historians and local historians about the history of the Daugavpils ghetto appeared. The author conditionally divided the works: first, written in the West and the United States, second, in the USSR, and third, in the Republic of Latvia. Such a comprehensive approach includes an ideological justification, preserves the chronology, place and language of the publication. The totality of all these works is the object of the study.

Keywords: Daugavpils, ghetto, historiography, books, memories, victims, Holocaust.

\section{1. Введение}

Тема Холокоста и связанного с ней такого понятия, как гетто, является неотъемлемой частью исследований в современной иудаике. Латвия, в частности город Даугавпилс, стала одним из центров еврейских гонений, однако история изучения этих событий наряду с другими важными событиями, повлиявшими на развитие города, складывалась весьма неоднозначна. Это было связано со многими факторами - как внешнеполитическими настроениями, так и самой особенностью данной тематики.

Данная статья посвящена анализу воспоминаний и исследований по истории Даугавпилсского гетто. Цель заключается в изучении темы гетто на примере города Даугавпилса.

\section{2. Материалы и методы}

Автор статьи изучил различного рода статьи, исследования и мемуары по теме Даугавпилсского гетто. Проанализированные материалы были разделены на группы в соответствии с обстоятельствами их появления. Выделены западный, советский и латышский или латвийский (после восстановления независимости Латвийской Республики) периоды в становлении и развитии историографии и источниковой базы. Сравнительный подход, выражавшийся в выявлении особенностей изучения истории Даугавпилсского гетто в разные периоды и у разных авторов, является основным методом исследования.

\footnotetext{
${ }^{*}$ Corresponding author

E-mail addresses: rochko@inbox.lv (I.G. Rochko)
} 


\section{3. Обсуждение и результаты}

3.1. Западная историография Даугавпилсского гетто. Одной из первых работ, описывающих Даугавпилсское гетто, стала вышедшая в Канаде в 1949 г. книга Песи Френкль-Залцман «Записки заключенной № 94771» (Frankel-Zaltzman, 2003)1. Номер 94771 ей был присвоен в Штуттгофе. Автор прошла мученический путь от ворот Даугавпилсского гетто через Кайзервальд и Штуттгоф и была освобождена в Быдгоще ${ }^{2}$. Свои воспоминания она начала писать сразу после освобождения.

Первые дни войны семья автора была сосредоточена только на спасении больного отца. Но уже в эти дни стали меняться представления женщины о войне, соседях, оккупантах. Горожане тут же обвиняли евреев, считая их коммунистами, т.е. абсолютным злом, их следовало уничтожить. Отношение местных жителей автор называет зверским. В многонациональном городе среди людей, преследовавших евреев, как правило, были люди разных национальностей. «Крики командиров слышны как удары: "Никто не смеет шагнуть на тротуар. Евреи должны работать и ходить по дороге как собаки”. Но даже переход через улицу был опасен. Люди кричали: «Скоро вы все будете расстреляны, как собаки. Вы все коммунисты!» (Frankel-Zaltzman, 2003). Вместе с тем автор воспоминаний отмечает, что не все были врагами евреев. Узница приводит ряд случаев сочувствия и помощи гонимым людям как со стороны оккупантов, так и со стороны полицейских. Не раз в «Записках» противопоставляется жизнь евреев и неевреев. Автор записок отметила, что «то же самое солнце заволокло на нашей стороне, в то время как на другой сияло» (Frankel-Zaltzman, 2003). Не зря в гетто родилась песня: «Для некоторых площади и бульвары, для нас такие кварталы...»3. Медсестра Песя находилась в центре событий, происходивших в больнице. Важным в воспоминаниях является то, что она дает список работников больницы, а также перечисляет их специальности.

Автор подробно описала самые крупные карательные акции, происходившие в гетто. П. Залцман-Френкель охарактеризовала и психологическое состояние узников. «Записки заключенной № 94771» значительно расширяют наши представления о гетто и его обитателях, их переживаниях и действиях. Здесь упоминается 84 персоны, из них восемьдесят - это узники гетто. Благодаря «Запискам заключенной № 94771» нам удалось узнать судьбу самой Песи Френкель-Залцман.

В том же 1949 г. в Нью-Йорке на идише вышла книга воспоминаний бывшего узника Даугавпилсского гетто Якова Расена «Мир вилн лебн» («Мы хотим жить»). Я. Расен, еврей из Каунаса, агроном по специальности, бежал из родного города, добрался до Даугавпилса, стал узником Даугавпилсского гетто, концентрационного лагеря Кайзервальд. Ему удалось сбежать из лагеря Дундага - Попервале. В лесу северной Курземе он случайно наткнулся на группу советских разведчиков. Этот счастливый случай спас ему жизнь. Позже Я. Расен попал в лагерь для «перемещенных лиц» в Германии, а затем уехал в Израиль. Находясь в лагере, автор начал писать свои воспоминания, которые поражают своей реальностью и в то же время воссоздают картину происшедшего (Rassen, 1949: 136-153).

В первые дни войны автор добрался до латвийско-белорусской границы к северовостоку от Двинска. Но тут его ждало страшное разочарование. Пересечь старую латвийскороссийскую границу беженцам не удалось. Он отмечал, что закрытие старой советской границы для беженцев обернулось трагедией: «Тут-то и началась беда, очень большая беда. Ехать дальше не позволяют. У границы уже собрались сотни беженцев из Литвы и Латвии и число их с каждым днем растет. Но на все их просьбы советская пограничная стража имела один ответ: "Приказано никого не пропускать! Отойдите на 20 шагов! Не то будем стрелять! Стреляем!”». Автор книги возложил ответственность на людские потери не только на нацистов, но и на советскую власть. Советские заградительные отряды на литовсколатвийской, а позже латвийско-российской границе не давали возможность беспрепятственно бежать в Россию. Эти задержки многим беженцам стоили жизни (Rassen, 1949: 22-29). Автор книги рассказал о событиях 1941-1943 гг. в Даугавпилсском гетто и лагерях, в которых он побывал. Одно из самых страшных воспоминаний - это описание

\footnotetext{
${ }^{1}$ Книга была написана на идише, а затем переведена на английский язык.

${ }^{2}$ Быдгощ - город в Польше.

3 Имелись в виду кварталы гетто.
} 
первомайской акции 1942 г. в гетто. Я. Расен день за днем описал события в гетто, а затем в Риге. Благодаря этой книге мы узнаем о буднях, повседневной жизни узников гетто.

В 1950-х гг. в Израиле на иврите вышла книга бывшей узницы Даугавпивпилсского гетто Минны Кантор «Не было ли это сном? Воспоминания о Двинском гетто» (Кантор, 1950) В основе книги 21-летней жительницы Даугавпилса лежат переживания и трагедия ее семьи. Ее удивляет и поражает отношение местных жителей к евреям. Уже в первые дни нацистской оккупации начались грабежи, оскорбления, грабежи, оскорбления, угрозы, отождествление евреев с коммунистами, стигматизация. Автор рассказывает о событиях в гетто. В августе 1941 г. она потеряла сестру, брата и мать. М. Кантор очень точно описывает психологическое состояние узников: «Не о чем говорить, все потеряно. Мы все... искалечены. Наш мир разрушен. Мы не люди, лишь тени. Сейчас люди понимают, что нет надежды на спасение».

7-8 ноября 1941 г. Минна Кантор сумела выскользнуть из гетто. Она пытается найти укрытие, но... «Нет у меня места под синим небом». Через неделю она возвратилась в гетто вместе с рабочими, которые трудились в городе. Ей удалось правдиво описать повседневную жизнь в гетто. Узница показала двойственность и трагедию руководителей юденрата и еврейской полиции.

В тоже время в воспоминаниях есть и радостные картины: спасение, помощь, любовь, описание просыпающейся природы весной 1943 г. Узница после Даугавпилса прошла мученический путь через лагеря Кайзервальд - Попервален - Дундага - Штуттогоф и оказалась в Германии. Освобождение она встретила 30 апреля 1945 г. около Мюнхена.

Она хотела выжить в этом нереальном мире. Выжила благодаря цепи случайностей. Бывшая узница сожалеет о погибших родных. М. Кантор написала книгу, чтобы сохранить память для будущих поколений. Она не пользовалась никакими документами. Воспоминания М. Кантор - это подлинный документ, воспоминания естественны, они лишены литературности. В этом их историческое и научное значение. В воспоминаниях нет упоминаний Бога, рассуждений кто виноват, почему евреи не эвакуировались.

После войны М. Кантор через Италию добралась до Палестины, работала учительницей. Ее дочь сказала автору, что она никогда не читала воспоминаний матери, даже то, что она рассказывала было так страшно. Неужели это был только сон?

В 1975 г. в Израиле вышел сборник «В памяти двинской общины» на иврите, где был помещен небольшой материал Рахель Фридман, узницы Даугавпилсского гетто, «Гетто Двинск». Автор свои воспоминания написала на иврите. Позже некоторые части воспоминаний были опубликованы в периодической печати ${ }^{1}$. Но подготовленный ею основной материал о гетто так и не увидел свет ${ }^{2}$ Р. Фридман попала в гетто, работала в одной из мастерских. В конце или начале октября 1941 г. Рахель Фридман удалось бежать из гетто. Ей помогли знакомые: учительница латышского языка, спрятавшая ее в подвале, домработница, давшая ей крестьянскую одежду.

Р. Фридман удалось добраться до Браславского гетто (Беларусь). В день его ликвидации она осталась в укрытии, а на следующий день ушла в лес. В июле 1942 г. она бродила по лесам, спала под кустами, ела ягоды, орехи, пока случайно не наткнулась на партизанский отряд. Здесь, как и другим евреям, ей пришлось столкнуться с подозрением в шпионаже и угрозой расстрела. В партизанском отряде она находилась до зимы 1943 г. Во время столкновения с немецким отрядом сумела бежать, обморозила ноги, вновь добралась до своих. После лечения училась, по доносу была арестована. В 1971 г. после 11 лет отказа выехала в Израиль. Дневник Рахиль Фридман можно оценить, как факт сопротивления нацизму. Всего несколько человек сумели бежать из гетто, добраться до белорусских партизан, выжить и написать о своей судьбе. Ее дальнейшая жизнь является ярким примером борьбы за достоинство еврея.

\footnotetext{
${ }^{1}$ Впервые отрывки из дневника Р. Фридман были опубликованы в еженедельнике «Секрет» (г. Петах - Тиква) в 2006 г. № 622, № 631, № 636, № 643, 4. 06, № 650, а затем в газете «Еврейский мир» (Нью-Йорк).

2 В Латвии впервые анализ воспоминаний помещен в статье И. Рочко «Последние свидетели (из истории Холокоста в Даугавпилсе и Латгалии)» (Рочко, 2010: 172-178).
} 
В 1990 г. в Нью-Йорке на английском языке вышла книга Сиднея Айвенса (Сидни Ивенса) «Как небеса темны: 1400 дней в тисках нацистского террора» (Ивенс, 2005) Литовский еврей, бежавший из Ионавы, достиг Даугавпилса, где попал в гетто. Несколько раз он чудом избежал расстрела, бежал к белорусским партизанам, а позднее попал в Шауляйское гетто, затем в концлагерь Штуттгоф. 30 апреля 1945 г. С. Ивенс был освобожден около Данцига. Он вернулся в Даугавпилсское гетто, где была любимая девушка. Он остался в городе и после 28 октября 1943 г., когда узники покинули крепость. С. Ивенс впервые описал, что десять евреев продолжали скрываться в Даугавпилсе.

Воспоминания С. Ивенса написаны в дневниковой форме. Он подробно, день за днем описывает события своей жизни в Даугавпилсском гетто, концлагерях, в которой присутствуют не только смерть и холод, голод и унижения, но и дружба, любовь и человеческое достоинство. С. Ивенс уверял автора, что свой дневник начал писать, находясь еще в гетто, однако это вызывает сомнение.

В 1997 г. в Тель-Авиве на русском языке вышла книга уроженки Краславы, Баси Цин «Выжить, чтобы вернуться» (Цин, 1997). В первые дни войны ее удивило, что руководитель города со своими знакомыми на машине спокойно отправились в Россию. На вопрос Б. Цин, в какую сторону бежать, председатель горисполкома ответил: «Зачем бежать? Вы что, не верите в силу нашей армии? Вы думаете, мы отдадим немцам Латвию? Никуда бежать не надо!». 27 июня 1941 г. Краслава была захвачена нацистами. Ее поразил грабеж, организованный представителями новой власти на глазах еще живых евреев. Одному из них понравилось обручальное кольцо Б. Цин, а также какая-то книга. На вопрос, для чего ему это надо, он ответил: «Хочу выбрать себе книгу на память о вас». Будущие убийцы уже знали судьбу своих жертв. Особенность уничтожения евреев в этом городе заключалась в том, что тридцать состоятельных семей пока оставили в относительном покое. Возможно, надеялись на получение от несчастных каких-то богатств. Летом 1941 г. порядка тысячи краславских евреев перегнали в Даугавпилсское гетто. Среди них была и семья автора книги. По дороге местные охранники грабили несчастных, расстреливали старых и отстающих. В гетто Б. Цин понесла страшные потери: погибли родители, муж, от голода умерла двухлетняя дочь. Б. Цин отметила, что судьба краславских узников была страшнее, чем местных. К местным могли прийти знакомые, передать через проволоку съестное. Сорокалетнюю женщину потряс эпизод, произошедший 9 ноября 1941 г.: «В гетто явился какой-то высокопоставленный немец. Всех молодых женщин поставили на колени, отобрали 50 человек и увели. Всем было понятно, что с ними будет. Но они вернулись. Некоторые в это время поседели, другие бились в истерике, третьи были в ужасе. Оказалось, что немцу исполнилось 50 лет, и поэтому он решил расстрелять 50 евреек. Извергу не удалось сделать себе “подарок”. Вмешалось гестапо, объяснив, что убивать - это их дело» (Рочко, 2003: 106).

В своей книге «Выжить, чтобы вернуться» бывшая узница Даугавпилсского гетто пытается понять, почему соседи евреев стали их убийцами. Некоторые говорили на идише, работали рядом с евреями, дружили с ними. Видимо, участие каждого из них в Катастрофе объясняется личными моральными качествами, которые персонифицированы в каждом человеке. По мнению Б. Цин, надо писать о Холокосте, это значит прокладывать мостик между прошлым и будущим ${ }^{1}$.

В 2002 г. в Лондоне на английском языке вышла книга Майи Абрамович (Зарх) «Простить... но не забыть: история Майи» (Abramowitch, 2002). Название ярко иллюстрирует отношение автора к происшедшему: она никогда не сможет, да и не смогла простить преступление и людей, его осуществивших.

До войны Майя Абрамович (Зарх) (1928 г.р.) жила в Даугавпилсе вместе с родителями и няней Петрунелой Вилимане. Автор книги с большим уважением и любовью писала о своей спасительнице. Был расстрелян отец девочки, а она с матерью ушла в гетто. Все свое имущество они оставили няне. П. Вилимане обещала беречь и сохранить еврейское добро.

\footnotetext{
1 В середине 1960-х гг. она выступила в качестве свидетельницы на нескольких судебных процессах против нацистских военных преступников в Риге, в начале 1990-х гг. вместе с писателем Л. Ковалем создала первое на территории бывшего СССР Общество бывших узников гетто и нацистских концлагерей. После эмиграции в Израиль в 1991 г. продолжала активно публиковаться.
} 
Нянечка приносила к воротам гетто еду, даже лесные ягоды. При этом спасительница сама голодала, рисковала, но помогала бывшим хозяевам. Иногда П. Вилимане ухитрялась передавать буханку хлеба, в которой была спрятана золотая монета или цепочка. Эти драгоценности спасали 12-летнюю девочку. Р. Зарх уходила на работу в город и брала с собой дочку. Она понимала, что ребенка могут в любой момент расстрелять. Так удалось пережить несколько кровавых акций. Охранники, получив драгоценности, «не замечали» Майю. Осенью 1942 г. за деньги охранник «не заметил», что мать вынесла ребенка, идя на работу в город. Но и здесь было небезопасно. Мать боялась за единственную дочь, которая боялась остаться без матери; спасители могли поплатиться жизнью. Майя вернулась в гетто. Гетто - место казни евреев - стало местом спасения девочки. 28 октября 1943 г. Ребекка Зарх вместе с другими узниками гетто были отправлены в Кайзервальд, а осенью 1944 г. в Шуттгоф. Обеим улыбнулось счастье - они выжили.

Каково же было изумление евреев, когда выяснилось, что Петрунела Вилимане не продала ни одной вещи, принадлежавшей еврейской семье, хотя она сама жила в крайней бедности. Книга М. Абрамович не только о гетто. Это книга о Праведнице, ее мужестве и скромности, и о спасении как форме сопротивлении.

В 2004 г. в Израиле на иврите увидела свет книга Хаима Курицкого «Уцелеть и рассказать» ${ }^{1}$ (Курицкий, 2004). Литовский еврей, бежавший из Утяны, достиг Даугавпилса, попал в тюрьму, затем в гетто, прошел ряд лагерей. В 1945 г. был освобожден американскими войсками ${ }^{2}$. Затем лечился в госпитале, служил в Красной армии. Хаим Курицкий в переписке с автором данной статьи утверждал, что стал вести дневник, находясь в гетто3. Х. Курицкий (1921, Утяны - 2017, Израиль), как и другие бывшие узники гетто, написал книгу, чтобы сохранить память о трагедии в годы Катастрофы. В то же время он отмечает болезненность воспоминаний о пережитом. Книга написана в форме дневника. Все события изложены в хронологическом порядке.

$\mathrm{X}$. Курицкий и его родные бежали из родного города. На старой литовско-латвийской границе беженцев проверил советский патруль. Через несколько дней Х. Курицкий оказался в тюрьме «Белый лебедь» в Даугавпилсе. Именно он первым описал эпизод коллективного сопротивления. Немецкий офицер вдруг обратился к евреям с предложением: «Если среди Вас найдётся миньян из 10 евреев, готовых к тому, чтобы их расстреляли, остальные останутся в живых!». Поднялось множество рук - все эти евреи были готовы идти на расстрел для того, чтобы их братья выжили (Курицкий, 2004: 20-21). Офицер неожиданно заявил: «Итак, я вижу представителей единого народа, каждый из которых, готов принести себя в жертву во имя блага остальных». Этот эпизод коллективного самопожертвования показывает, что дух евреев не был сломлен.

Автор описывает массовый расстрел мужчин в саду за тюрьмой. Подошла очередь Х. Курицкого. И тут случилось чудо: оказалось, что ров заполнен до конца, и еврею было приказано трамбовать еще шевелящиеся тела. В гетто он стал «ремесленником», выполнявшим различные работы. Точно автор описал крупнейшие акции по уничтожению евреев, в том числе и события 18-19 августа 1941 г., когда группа немецких солдат спасла жизнь ему и другим узникам.

Вместе с тем бывший узник с огромной теплотой вспоминал своих товарищей по несчастью: их отношение друг к другу, вспыхнувшую любовь. После Даугавпилсского гетто ему предстояло пройти Кайзервальд, работу в Магдебурге, дожить до Победы.

Большинство выживших узников гетто не оставили своих воспоминаний, упомянув только, что они были в аду. Возможно, они боялись вновь пережить то, что невозможно даже вообразить. Они говорили автору: «Ни один рассказ, ни один кинофильм, ни один человек, не бывший “там”, никогда не сможет даже представить, что мы пережили». Но большинство их имели только среднее образование, и им было трудно логично изложить пережитое. Любая книга, правдиво рассказывающая о Катастрофе, является частью художественного мемориала.

\footnotetext{
1 В настоящее время доступна книга и на русском языке. Автор данной статьи переписывался с бывшим узником гетто. В 2020 г. книга была издана на литовском языке.

2 Анализ книги содержится в очерке И. Рочко «О книге Х. Курицкого “Уцелеть и рассказать” (Рочко, 2010: 236- 253).

3 Автор сомневается, что в нечеловеческих условиях гетто и концлагерей можно вести дневник.
} 
Этот мемориал, созданный страданиями людей, обвиняет не только нацистов, их пособников, но и все человечество. Ведь большая часть человечества достаточно хладнокровно наблюдала за Катастрофой. Но писать и исследовать Катастрофу нужно не с целью отмщения, а с целью, чтобы такие трагедии более не повторялись (Frankel-Zaltzman, 2003). Любое воспоминание бывшего узника - это и форма борьбы против нацизма.

3.2. Советская историография Холокоста в Латгалии. Первым упоминанием Катастрофы еще во время войны стала публикация в 1945 г. Р. Ковнатор в московской газете «Эйникайт» на идише «Сёма Шпунгин» ${ }^{1}$ (Ковнатор, 1945). В статье рассказывается о мучениях еврейского подростка С. Шпунгина в гетто и побеге из Даугавпилсского гетто. В ней делался акцент на страдания евреев, но и отмечалось, что мальчик спасся благодаря помощи местных жителей ${ }^{2}$.

И лишь один человек продолжал собирать воспоминания, искать документы о Даугавпилсском гетто. Это Залман Якуб - известный в Даугавпилсе краевед и историк Не имея исторического образования, он совершил моральный подвиг, написав очерк о гетто. В 1987 г. в единственном СССР журнале, выходящем на идише, «Советиш Геймланд» в трех номерах (№5, №8 и №9) был опубликован в сокращенном виде очерк 3. Якуба «В те дни». В 1993 г. еврейская община города Даугавпилс издала первую книгу «Евреи в Даугавпилсе. Исторические эссе», где была напечатана вся работа З. Якуба на русском языке (Якуб, 1993: 287-395). Эту работу также перевели на иврит, и она увидела свет в Израиле4. Это прекрасный и непреходящий памятник мученикам Даугавпилсского гетто, который не может оставить никого равнодушным. Очерк имеет и научное значение, т.к. его автор сумел собрать воспоминания тех, кто пережил Холокост. В работе раскрывается картина произошедшего в городской тюрьме, рядом с которой были расстреляны тысяча местных и литовских евреев-мужчин. Тщательно изложена жизнь в гетто, в т.ч. больницы, юденрата, и описаны крупнейшие акции по уничтожению узников гетто. Много места уделено спасателям и спасенным, работе в городских мастерских, попыткам оказать сопротивление. Такое всестороннее описание трагедии даже родило мысль, что трагедия исследована и больше нет смысла, что-то искать.

3.3. Историография Даугавпилсского гетто в независимой Латвии. В середине начался 1990-х гг. начался новый период не только сбора информации, но и осмысления еврейской Катастрофы. Необходимо отметить огромный вклад Латвийской Комиссии историков Латвии в изучении еврейской трагедии. Ведущие историки страны, изучающие Катастрофу, такие как М. Вестерманис, Р. Виксне, К. Кангерис, А. Странга, Х. Стродс, А. Уртанс, Д. Эрглис и другие, исследовали в основном этот вопрос в Латвии, а также в Латгалии. Например, М. Вестерманис в очерке «Холокост в Латвии.

\footnotetext{
${ }^{1}$ Газета «Эйникайт» («Единство») выходила на идише с ноября 1942 г. по ноябрь 1948 г. Ковнатор Рахиль (1899, Грива - 1977, Москва) - историк, филолог, редактор. В начале 1930-х гг. Р. Ковнатор редактировала рукопись «Как закалялась сталь» Н. Островского, переписывалась с писателем. В 1943 г. опубликовала биографический очерк «Мать Ленина». Во время Второй мировой войны она работала в Еврейском антифашистском комитете и публиковалась в газете «Эйникайт». Она написала ряд текстов для «Чёрной книги», вышедшей под редакцией И. Эренбурга и В. Гроссмана. Журналист участвовала в подготовке издания «М. Горький в воспоминаниях современников». Ее заслугой в 1950-х - 1960-х гг. являлось участие в издании «Московский университет в воспоминаниях». Ее перу принадлежат две публикации на идише о евреях - Героях Советского Союза: Иосифе Маковском и Полине Гельман. В ГДР о ней писали, как одной из знаменитых женщин в первые годы советской власти. Возможно, журналиста заинтересовала судьба даугавпилсского мальчика, т.к. она была родом из этих же мест (Рочко, 2019: 38-41).

2 Первым об этой статье упоминает Г. Маймин (Маймин, 2010).

зЯкуб Залман (1919, Даугавпилс - 2009, Даугавпилс), краевед, историк, участник войны, автор и соавтор нескольких книг, опубликовал более 600 статей на русском, латышском языках, иврите и идише в журналах и газетах Москвы, Риги, Биробиджана, Даугавпилса, Варшавы, Тель-Авива.

4 Перевод с идиша на русский язык осуществили Л. Левитан и И. Штейман.
} 
Историографический обзор» показал, как рождалась историография этого вопроса в Латвии (Vestermanis, 1992)1.

Все названные публикации не давали ясный ответ на фундаментальный вопрос: «Кто виноват?». Узники гетто, зачастую всю вину возлагали на местных пособников нацистов, иногда на немецких офицеров, которые руководили операциями по уничтожению евреев. Но эти лейтенанты и майоры осуществляли политику фашистского государства. Конечно, бывшие узники каждый день видели в гетто своих мучителей. Им казалось, что именно они во всем виноваты. Наиболее значительной научной работой, посвященной Холокосту в Латвии, стал труд американского профессора латышского происхождения А. Эзергайлиса «Холокост в оккупированной немцами Латвии, 1941-1944» (в английском варианте «Отсутствующий центр»), вышедший в 1996 г. $^{2}$ (Ezergailis, 1999). На долгое время книга стала классической работой по изучению Холокоста.

В рассматриваемом труде А. Эзергайлис выдвинул и обосновал идею, суть которой в следующем: если бы не было немецкой оккупации, то не было и Холокоста. Да, антисемитизм всегда существовал, но массового уничтожения не было. Отсюда вывод: виноват немецкий нацизм, а местные коллаборационисты были лишь исполнителями воли оккупантов. Такова обычная точка зрения западных историков, а также большинства историков Латвии. В годы Катастрофы не существовало независимого латвийского государства. На этот момент указывает второе название книги - «Отсутствующий центр». Значит, никто не несет политической ответственности за преступление местных жителей. Личная моральная ответственность может быть возложена только на убийц.

Историк исследовал деятельность специальных команд эйнзацгрупп («группы полной готовности») в Даугавпилсе. А. Эзергайлис упоминает четыре крупнейшие акции по уничтожению узников гетто. Он также объективно рассчитал количество жертв-евреев в Даугавпилсе, которое он оценил в 13000.

В 2010 г. М. Мелер опубликовал монографию «Места нашей памяти. Еврейские общины, уничтоженные в Холокосте» (Мелер, 2010). На взгляд автора, монография М. Мелера - классический труд, который охватывает Катастрофу во всех городах и населенных пунктах Латвии и Латгалии. Простое перечисление населенных пунктов Латгалии, которые М. Мелер изучил, показывает всеохватывающий характер исследования. Усилиями одного человека и его добровольных помощников в течение восьми лет была создана уникальная энциклопедия Холокоста в Латвии. Он описал историю Даугавпилсского гетто, используя огромный архивный материал, а также исследования даугавпилсских ученых (Мелер, 2010: 134-154).

В 2003 г. группа даугавпилсских историков издала книгу «Холокост в Латгалии» (Волкович и др., 2003). Автор данной статьи для упомянутой книги написал очерк «Спасенные, спасение, спасатели». В рассматриваемом очерке предпринята попытка воссоздать картину жизни и гибели евреев Даугавпилса. В работе использованы воспоминания тех, кто выжил в гетто, сумел спастись от уничтожения, благодаря спасителям, а также воспоминания спасителей и неевреев, которые были свидетелями трагедии. Такой подход позволил показать объективную картину событий. Рассмотрена психология узников и психология убийц, а также «молчаливого большинства» или «стоящих в стороне». Анализ последних воспоминаний - фактически рассказ о Катастрофе нееврейскими глазами. Их представления лучше позволяют понять обстоятельства спасения евреев и сотрудничества части местных жителей с оккупационными властями. Автор пришел к мнению, что помочь еврею - означало не подчиниться приказам оккупационного режима. Спасти еврея - это значит оказать активное сопротивление нацизму и их местным коллаборационистам.

\section{4. Заключение}

Тема гетто и Холокоста до конца не изучена, однако сохранившиеся воспоминания узников гетто и публикации советских, западных и латвийских исследователей помогают

\footnotetext{
1 Это исследование дополнялось в последующих публикациях (Vestermanis, 2001; Vestermanis, 2007).

2 Изначально исследование было опубликовано на английском языке. Через три года книга вышла на латышском языке.
} 
глубже раскрыть эту непростую тему - катастрофу, которая коснулась огромной территории бывшего СССР. На примере изучения истории Даугавпилсского гетто, автор статьи продемонстрировал многообразие подходов к изучению данного вопроса, а также то, как менялись представления тех, кто отваживался что-либо публиковать по данной теме.

\section{Литература}

Волкович и др., 2002 - Волкович Б., Олехнович Д., Рочко И., Сташевский М., Шнеер А., Штейман И. Холокост в Латгалии. Даугавпилс: Даугавпилсская еврейская община, 2003. $146 \mathrm{c}$.

Ивенс, 2005 - Ивенс С. Как небеса темны: 1400 дней в тисках нацистского террора. Пер. Е.В. Осенева, ред. И. Парина. М.: Аграф, 2005. 396 с.

Кантор, 1950 - Кантор $M$. Не было ли это сном? Воспоминания о Двинском гетто. [Б. м., б. г. (Израиль)]. 1950. 78 с. (иврит).

Ковнатор, 1945 - Ковнатор Р. Сёма Шпунгин // Эйникайт. 1945. 3 марта.

Курицкий, 2004 - Курицкий X. Уцелеть и рассказать. Тель-Авив, 2004. 121 с. (иврит).

Маймин, 2010 - Маймин Г. Они пережили холокост // Личный архив И. Рочко.

Мелер, 2010 - Мелер M. Места нашей памяти: еврейские общины Латвии, уничтоженные в Холокосте. Рига: Рижская еврейская община, музей «Евреи в Латвии», 2010. $471 \mathrm{c}$.

Рочко, 2003 - Рочко И. Жертвы, спасённые, спасатели. Холокост в Латгалии. Даугавпилс: Даугавпилсская еврейская община, 2003. 146 с.

Рочко, 2010 - Рочко И. Евреи в Латгалии: исторические очерки. Кн. 1. Музей «Евреи в Даугавпилсе и Латгалии» Даугавпилсской религиозной общины и еврейского общества. Даугавпилс: [Б.и.], 2010. 482 с.

Рочко, 2019 - Рочко И. Знаменитые евреи Латгалии. Кн. 2 / Ред. Г. Рочко. Даугавпилс: [Б.и.], 2019. 532 с.

Цин, 1997 - Цин Б. Выжить, чтобы вернуться: документальная повесть. Тель-Авив: Библиотека Матвея Черного. 1997. 259 с.

Якуб, 1993 - Якуб 3. В те дни: из истории Даугавпилсского гетто. // Евреи в Даугавпилсе. Исторические эссе. Даугавпилс: Даугавпилсская еврейская община. 1993. C. $287-395$.

Abramowitch, 2002 - Abramowitch $M$. To forgive... but not forget: Maja's story. London: Vallentine Mitchell. 2002. 136 p.

Ezergailis, 1999 - Ezergailis A. Holokausts vācu okupētajā Latvijā. 1941-1944. Rīga: Latvijas Vēstures institūta apgàds, 1999. 591 l.

Frankel-Zaltzman, 2003 - Frankel-Zaltzman P. Haftling (Prisoner) No. 94771. Holocaust Memoirs / Ed. by M.M. Shafir. Published by The Concordia University Chair in Canadian Jewish Studies and The Montreal Institute for Genocide and Human Rights Studies. 2003 [Электронный pecypc]. URL: http://migs.concordia.ca/memoirs/frankel_zaltzman_paula/frankel_zaltzman_ paula_intro.htm (дата обращения: 04.05.2021).

Rassen, 1949 - Rassen J. Mir viln lebn. New York: Kedem Press. 1949. 122 p.

Vestermanis, 1992 - Vestermanis M. Holokausts Latvijā: Historiogrāfisks apskats // Ārzemju literatūra par Latviju. Rīga: Zinātne, Zinātne, 1992. L. 122-135.

Vestermanis, 2001 - Vestermanis M. Holokausts Latvijā. Historiogrāfisks apskats // Holokausta izpētes problēmas Latvijā: Starptautiskās konferences referāti 2000. gada 16-17. oktobris. Rīga: Latvijas vēstures institūta apgāds, 2001. L. 36-49.

Vestermanis, 2007 - Vestermanis M. Holokausts Latvijā. Historiogrāfisks apskats // Pētijumi par holokaustu Latvijā. Latvijas Vēsturnieku Komisijas raksti. 2. sējums. Otrais izdevums. Rīga: Latvijas vēstures institūta apgāds, 2007. L. 36-48

\section{References}

Abramowitch, 2002 - Abramowitch, M. (2002). To forgive... but not forget: Maja's story. London: Vallentine Mitchell, 136 p.

Ezergailis, 1999 - Ezergailis, A. (1999). Holokausts vācu okupētajā Latvijā. 1941-1944 [Holocaust in German-occupied Latvia. 1941-1944]. Rìga, 591 p. [in Latvian] 
Frankel-Zaltzman, 2003 - Frankel-Zaltzman, P. (2003). Haftling (Prisoner) No. 94771. Holocaust Memoirs. Ed. by M.M. Shafir. Published by The Concordia University Chair in Canadian Jewish Studies and The Montreal Institute for Genocide and Human Rights Studies. [Electronic resource]. URL: http://migs.concordia.ca/memoirs/frankel_zaltzman_paula/frankel_zaltzman_ paula_intro.htm (date of access: 04.05.2021)

Ivens, 2005 - Ivens, $S$. (2005). Kak nebesa temny: 1400 dnei v tiskakh natsistskogo terrora [How the skies are dark: 1400 days in the grip of Nazi terror]. Transl. Oseneva E., ed. Parina I. Moscow: Agraf, 396 p. [in Russian]

Kantor, 1950 - Kantor, M. (1950). Ne bylo li eto snom? Vospominaniya o Dvinskom getto [Was it a dream? Memories of the Dvina ghetto] [a.m., a. d.], 78 p. [in Hebrew]

Kovnator, 1945 - Kovnator, R. (1945). Sema Shpungin. Einikait. 1945. March 3. [in Russian] Kuritskii, 2004 - Kuritskii, Kh. (2004). Utselet' i rasskazat' [Survive and tell]. Tel'-Aviv, 121 p. [in Hebrew]

Maimin, 2010 - Maimin, G. (2010). Oni perezhili kholokost [They survived the Holocaust]. Personal archive of I. Rochko [in Russian]

Meler, 2010 - Meler, M. (2010). Mesta nashei pamyati: evreiskie obshchiny Latvii, unichtozhennye $\mathrm{v}$ Kholokoste [Places of our memory: Jewish communities of Latvia destroyed in the Holocaust]. Riga: Rizhskaya evreiskaya obshchina, muzei "Evrei v Latvii”, 471 p. [in Russian]

Rassen, 1949 - Rassen, J. (1949). Mir viln lebn... Kedem Press. New York, 122 p.

Rochko, 2003 - Rochko, I. (2003). Zhertvy, spasennye, spasateli. Kholokost v Latgalii [Victims, rescued, rescuers. The Holocaust in Latgale] Daugavpils: Daugavpilsskaya evreyskaya obshchina, 146 p. [in Russian]

Rochko, 2010 - Rochko, I. (2010). Evrei v Latgalii: istoricheskie ocherki [Jews in Latgale: historical essays]. Book 1. Muzei "Evrei v Daugavpilse i Latgalii” Daugavpilsskoi religioznoi obshchiny i evreiskogo obshchestva [Museum "Jews in Daugavpils and Latgale" of the Daugavpils Jewish community and Daugavpils Jewish religious society]. Daugavpils: [a.m.], 146 p. [in Russian]

Rochko, 2019 - Rochko, I. (2019). Znamenitye evrei Latgalii [Famous Jews of Latgale]. Book 2 / ed. G. Rochko. Daugavpils: [a.m], 532 p. [in Russian]

Tsin, 1997 - Tsin, B. (1997). Vyzhit', chtoby vernut'sya: dokumental'naya povest' [Survive to return: a documentary story]. Tel'-Aviv: Biblioteka Matveya Chernogo. 259 p. [in Russian]

Vestermanis, 1992 - Vestermanis, M. (1992). Holokausts Latvijā: Historiogrāfisks apskats [The Holocaust in Latvia: historiographic review]. Ārzemju literatūra par Latviju [Foreign literature about Latvia]. Rīga: Zinātne, pp. 122-135. [in Latvian]

Vestermanis, 2001 - Vestermanis, M. (2001). Holokausts Latvijā. Historiogrāfisks apskats [The Holocaust in Latvia: historiographic review]. Holokausta izpētes problēmas Latvijā: Starptautiskās konferences referāti 2000. gada 16-17 oktobris [Problems of Holocaust Research in Latvia: international conference reports October 16-17, 2000]. Rīga, 36-49 [in Latvian]

Vestermanis, 2007 - Vestermanis, M. (2007). Holokausts Latvijā. Historiogrāfisks apskats. [The Holocaust in Latvia: historiographic review]. Pētijumi par holokaustu Latvijā. Latvijas Vēsturnieku Komisijas raksti [Research on the Holocaust in Latvia. Articles by the Latvian Commission of historians]. 2. sējums. Otrais izdevums. Rīga: Latvijas vēstures institūta apgāds, pp. 36-48. [in Latvian]

Volkovich et al., 2003 - Volkovich, B., Olekhnovich, D., Rochko, I., Stashevskii, M., Shneer, A., Shteiman, I. (2003). Kholokost v Latgalii [The Holocaust in Latgale]. Daugavpils: Daugavpilsskaya evreyskaya obshchina, 146 p. [in Russian]

Yakub, 1993 - Yakub, Z. (1993). V te dni: iz istorii Daugavpilsskogo getto [In those days: from the history of the Daugavpils ghetto]. Evrei v Daugavpilse. Istoricheskie esse [Jews in Daugavpils. Historical essays]. Daugavpils: Daugavpilsskaya evreyskaya obshchina, pp. 287-395. [in Russian] 


\section{Мемуары и исследования по истории Даугавпилсского гетто}

Иосиф Гершонович Рочко ${ }^{\text {, * }}$

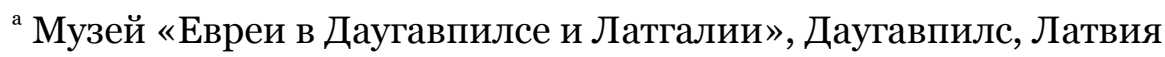

Аннотация. Даугавпилсское гетто существовало с 15 июля 1941 г. по 28 октября 1943 г. Через ворота гетто прошли более 13000 евреев. Выжили немногим более 100. В гетто находились евреи Даугавпилса и окрестностей, небольших городов и местечек Латгалии, а также несколько тысяч евреев из Литвы. Около десяти бывших узников оставили дневники и воспоминания о тех страшных днях, которые опубликованы и дошли до наших дней. Позже появились работы ученых-историков, краеведов об истории Даугавпилсского гетто. Автор условно разделил работы: во-первых, написанные на Западе и США, во-вторых, - в СССР, в-третьих, в Латвийской Республике. Такой комплексный подход включает в себя идеологическое обоснование, сохраняет хронологию, место и язык издания. Совокупность всех этих работ составляет предмет исследования.

Ключевые слова: Даугавпилс, гетто, историография, книги, воспоминания, жертвы, Холокост.

\footnotetext{
* Корреспондирующий автор Адреса электронной почты: rochko@inbox.lv (И.Г. Рочко)
} 